\author{
Zbigniew Zioło \\ Zakład Przedsiębiorczości i Gospodarki Przestrzennej \\ Instytut Geografii \\ Akademia Pedagogiczna, Kraków
}

\title{
Światowe uwarunkowania rozwoju przedsiębiorczości
}

W warunkach wdrażania reguł gospodarki rynkowej ważną rolę odgrywa znajomość procesów gospodarczych dokonujących się w otoczeniu przedsiębiorstwa produkcyjnego, czy usługowego, a także różnego typu instytucji, np. finansowych czy edukacyjnych. W zależności od ich przestrzennego zasięgu oddziaływania (w zakresie powiązań aktywnych i pasywnych oraz możliwości oddziaływania na nich zewnętrznych impulsów pobudzających, czy ograniczających ich rozwój), można umownie wyróżnić otoczenie: lokalne, ponadlokalne, regionalne, subregionalne, regionalne, krajowe, europejskie, czy światowe. Każde z wyróżnionych kategorii otoczenia charakteryzuje się odmiennymi regułami rozwoju, a także stwarza często odmienne uwarunkowania dla możliwości podejmowania decyzji i rozwoju działalności gospodarczej. Analiza funkcjonowania i określania możliwości rozwoju jednostek w wyróżnionych umownie układach otoczenia, nawiązuje do znanej już powszechnie tezy: myśl globalnie - działaj lokalnie, która oznacza, iż dla sprawnego działania danego przedsiębiorstwa, czy instytucji, a także dowolnego układu przestrzennego, niezbędne jest rozumienie procesów dokonujących się w ich otoczeniu, np. krajowym, europejskim, czy światowym.

W świetle przedstawionych założeń w niniejszych rozważaniach będziemy zmierzać do określenia tendencji zmian światowych uwarunkowań rozwoju przedsiębiorczości, poprzez zmiany wartości Produktu Krajowego Brutto (PKB), który jest powszechnie przyjmowany jako syntetyczny miernik zarówno światowego potencjału gospodarczego jak i potencjału gospodarczego krajów, a także regionów. PKB obrazuje bowiem końcowy rezultat działalności wszystkich podmiotów gospodarki narodowej i równa się sumie wartości dodanej wszystkich sektorów instytucjonalnych lub sumie wartości dodanej brutto wszystkich sekcji gospodarki narodowej, powiększonej o podatki od produktów i pomniejszonej o dotacje.

Współcześnie charakterystyczną cechą otoczenia światowego jest nasilający się proces koncentracji kapitału, który uwidacznia się w kształtowaniu się coraz potężniejszych ponadnarodowych korporacji przemysłowych, finansowych, usługowych i in. Obejmują one swoim zasięgiem coraz to rozleglejsze obszary oddziaływania i wpływają w głównym stopniu na różnicowanie światowej przestrzeni gospodarczej, społecznej i kulturowej ${ }^{1}$. Zróżnicowana przestrzeń geograficzna stwarza bowiem odmienne warunki rozwoju, które wpływają na atrakcyjność poszczególnych obszarów dla wkraczania i kształtowania się różnych form działalności produkcyjnej, usługowej oraz dają określone możliwości dla pogłębiania istniejących i opanowywania nowych rynków. Uwarunkowania przestrzeni geograficznej wpływają więc bądź na nasilanie się procesów polaryzacyjnych, które prowadzą do postępującego różnicowania poziomu rozwoju poszczególnych krajów czy regionów, bądź do wy-

\footnotetext{
${ }^{1}$ Zioło Z., Model przestrzeni geograficznej i jej znaczenie dla gospodarki przestrzennej [w:] Gospodarka-Przestrzeń-Środowisko (red. U. Wich), Wyd. UMCS, Lublin 1996, s. 183-191.
} 
równywania wcześniej już wykształconych dysproporcji. Może to być ważną informacją dla różnego typu firm, które zamierzają poszukiwać nowych rynków zaopatrzeniowych czy rynków zbytu, powiązań kapitałowych, organizacyjnych i in.

W latach 1990-2003 światowa wartość PKB systematycznie wzrastała z 21,8 bil. dol. USD do 32,3 bil. dol. USD, czyli do $148,1 \%^{2}$. Ten ogólny światowy proces wzrostu gospodarczego jest wynikiem zróżnicowanych uwarunkowań rozwoju występujących na terenie poszczególnych krajów (tab. 1).

Tab. 1. Zmiana wartości Produktu Krajowego Brutto w latach 1990-2003.

\begin{tabular}{|c|c|c|c|c|c|c|c|}
\hline \multirow[t]{2}{*}{ Kraje } & \multicolumn{2}{|c|}{ PKB w mld dol. USA } & \multirow{2}{*}{$\begin{array}{c}\text { Dynamika } \\
1990-2003 \\
(1990=100)\end{array}$} & \multicolumn{2}{|c|}{ Udział PKB w świecie } & \multicolumn{2}{|c|}{ Udział } \\
\hline & 1990 & 2003 & & 1990 & 2003 & powierzchni & ludności \\
\hline Świat & 21817 & 32312 & 148,1 & 100,0 & 100,0 & 100,0 & 100,0 \\
\hline Stany Zjednoczone & 5751 & 10934 & 190,1 & 26,4 & 33,8 & 6,9 & 4,7 \\
\hline Japonia & 3052 & 4301 & 140,9 & 14,0 & 13,3 & 0,3 & 2,1 \\
\hline Niemcy & 1689 & 2403 & 142,3 & 7,7 & 7,4 & 0,3 & 1,3 \\
\hline W. Brytania & 990 & 1795 & 181,4 & 4,5 & 5,6 & 0,1 & 0,2 \\
\hline Francja & 1216 & 1758 & 144,5 & 5,6 & 5,4 & 0,4 & 1,0 \\
\hline Włochy & 1102 & 1468 & 133,2 & 5,1 & 4,5 & 0,2 & 0,9 \\
\hline Chiny & 355 & 1266 & 357,1 & 1,6 & 3,9 & 7,1 & 20,8 \\
\hline Kanada & 576 & 854 & 148,3 & 2,6 & 2,6 & 7,4 & 0,5 \\
\hline Hiszpania & 514 & 839 & 163,3 & 2,4 & 2,6 & 0,4 & 0,6 \\
\hline Meksyk & 263 & 626 & 238,1 & 1,2 & 1,9 & 1,4 & 1,7 \\
\hline Rep. Korei & 253 & 605 & 239,7 & 1,2 & 1,9 & 0,1 & 0,8 \\
\hline Australia & 310 & 519 & 167,2 & 1,4 & 1,6 & 5,7 & 0,3 \\
\hline Holandia & 294 & 512 & 174,0 & 1,3 & 1,6 & 0,0 & 0,3 \\
\hline Indie & 317 & 510 & 161,0 & 1,5 & 1,6 & 2,4 & 16,6 \\
\hline Brazylia & 465 & 452 & 97,3 & 2,1 & 1,4 & 6,3 & 2,8 \\
\hline Rosja & 579 & 347 & 59,8 & 2,7 & 1,1 & 12,6 & 2,3 \\
\hline Szwajcaria & 228 & 320 & 140,1 & 1,0 & 1,0 & 0,0 & 0,1 \\
\hline Belgia & 199 & 302 & 151,9 & 0,9 & 0,9 & 0,0 & 0,2 \\
\hline Szwecja & 238 & 302 & 126,6 & 1,1 & 0,9 & 0,3 & 0,1 \\
\hline Austria & 182 & 253 & 139,3 & 0,8 & 0,8 & 0,1 & 0,1 \\
\hline Turcja & 151 & 240 & 159,1 & 0,7 & 0,7 & 0,6 & 1,1 \\
\hline Norwegia & 116 & 221 & 191,3 & 0,5 & 0,7 & 0,2 & 0,1 \\
\hline Dania & 133 & 212 & 158,8 & 0,6 & 0,7 & 0,0 & 0,1 \\
\hline Polska & 127 & 210 & 164,9 & 0,6 & 0,6 & 0,2 & 0,6 \\
\hline Grecja & 84 & 172 & 204,8 & 0,4 & 0,5 & 0,1 & 0,2 \\
\hline Finlandia & 137 & 162 & 118,3 & 0,6 & 0,5 & 0,2 & 0,1 \\
\hline Irlandia & 47 & 149 & 314,8 & 0,2 & 0,5 & 0,1 & 0,1 \\
\hline Portugalia & 72 & 148 & 206,6 & 0,3 & 0,5 & 0,1 & 0,2 \\
\hline Rep. Pd. Afryki & 112 & 104 & 93,0 & 0,5 & 0,3 & 0,9 & 0,7 \\
\hline Argentyna & 141 & 102 & 72,1 & 0,6 & 0,3 & 2,1 & 0,6 \\
\hline Rep. Czeska & 30 & 85 & 288,5 & 0,1 & 0,3 & 0,1 & 0,2 \\
\hline Węgry & 94 & 83 & 88,4 & 0,4 & 0,3 & 0,1 & 1,0 \\
\hline Nowa Zelandia & 44 & 79 & 181,2 & 0,2 & 0,2 & 0,2 & 0,1 \\
\hline Rumunia & 38 & 46 & 119,3 & 0,2 & 0,1 & 0,2 & 0,4 \\
\hline Ukraina & 91 & 42 & 45,5 & 0,4 & 0,1 & 0,4 & 0,8 \\
\hline Słowacja & 13 & 33 & 255,9 & 0,1 & 0,1 & 0,0 & 0,1 \\
\hline Luksemburg & 11 & 27 & 240,9 & 0,1 & 0,1 & 0,0 & 0,0 \\
\hline Słowenia & 13 & 22 & 173,2 & 0,1 & 0,1 & 0,0 & 0,0 \\
\hline Bułgaria & 21 & 16 & 74,9 & 0,1 & 0,0 & 0,1 & 0,1 \\
\hline Białoruś & 35 & 14 & 40,6 & 0,2 & 0,0 & 0,2 & 0,2 \\
\hline Litwa & 13 & 14 & 103,8 & 0,1 & 0,0 & 0,0 & 0,1 \\
\hline Estonia & 7 & 9 & 129,4 & 0,0 & 0,0 & 0,0 & 0,0 \\
\hline Łotwa & 13 & 8 & 67,2 & 0,1 & 0,0 & 0,0 & 0,0 \\
\hline
\end{tabular}

Źródło: GUS. Rocznik statystyczny, 2002, s. 734; 2004, s. 847.

${ }^{2} \mathrm{~W}$ niniejszej pracy wykorzystano część danych statystycznych zawartych w artykule Kudełko J., Zioło Z., Przemiany potencjału gospodarczego przestrzeni światowej w latach 1990-2003, złożonej do druku w Wyd. Uniwersytetu Opolskiego. 
W światowym procesie przemian dominująca rolę odgrywają Stany Zjednoczone, które stopniowo umacniają swoją pozycję w potencjale gospodarki światowej. Wyrazem tego jest zwiększanie się wartości PKB z 5,7 mld w 1990 r. do 10,9 mld dol. w 2003 r., tj. do $190 \%$, oraz zwiększający się ich udział w światowym potencjale gospodarczym z 26,4\% do 33,8\%. Kolejną pozycję zajmowała Japonia, której PKB zwiększył się w tym czasie z 3,1 bil. dol. do 4,8 bil. dol., tj. do $140,9 \%$, ale jej udział w światowym potencjale gospodarczym zmniejszył się z 14,0\% do 13,3\%. Trzecią pozycję zajmują Niemcy, których udział w światowej gospodarce wykazywał pewne wahania i również zmniejszył się z 7,7\% do 7,4\% w 2003 r. Umacnia swoją czwartą pozycję Wielka Brytania, której udział w światowej gospodarce systematycznie zwiększał się z 4,1\% w 1995 r. do 5,6\% w 2003 r. Podobnymi tendencjami jak gospodarka Niemiec, charakteryzowała się gospodarka Francji, której udział w światowym PKB zmniejszył się 5,6\% do 5,4\%. Systematycznie zmniejszała swoją pozycję gospodarka Włoch, czego wyrazem jest spadek jej udziału w gospodarcze światowej z 5,1\% do $4,5 \%$.

Systematycznym wzrostem udziału w potencjale światowym cechowała się gospodarka Chin, której udział systematycznie zwiększał się z 1,3\% do 3,9\%. Pozostałe kraje odgrywają zdecydowanie mniejszą rolę w gospodarce światowej obejmując w 2003 r. poniżej 2,3\% światowego produktu brutto. W tej grupie krajów znalazła się Polska, której udział W gospodarce światowej jest stosunkowo niewielki i utrzymywał się na poziomie $0,5 \%$ $0,6 \%$.

Charakterystyczną cechą światowej gospodarki jest bardzo duża koncentracja przestrzenne i demograficzna potencjału gospodarczego. Podkreśla to relacja udziałów PKB poszczególnych krajów w stosunku do udziału ludności i zajmowanej powierzchni.

W 2003 r. dominującą pozycję w światowym potencjale gospodarczym utrzymują Stany Zjednoczone, które skupiają 33,8\% wartości PKB, obejmując tylko 6,9\% obszaru świata, na którym mieszka 4,7\% ludności świata. Druga pod względem potencjału gospodarczego Japonia obejmuje 13,3\% światowego PKB oraz 0,3\% obszaru, na którym skupia się $2,1 \%$ ludności. Te dwa wiodące kraje w gospodarce światowej w $1990 \mathrm{r}$. koncentrowały 40,4\% światowego potencjału gospodarczego, a w następnych latach ich udział zwiększył się do 47,1\% w 2003 r., podczas gdy obejmowały łącznie tylko 6,8\% ludności świata i 7,2\% powierzchni.

Odwrotne relacje zaznaczają się w krajach o największym obszarze i potencjale demograficznym. Chiny, skupiające aż $20,8 \%$ ludności na obszarze obejmującym $7,1 \%$ powierzchni ziemi, zwiększyły swój udział w potencjale gospodarczym z 1,6\% do 3,9\%; na obszarze Indii, obejmującym 16,6\% ludności, udział w światowym potencjale gospodarczym utrzymuje się na poziomie 1,5-1,6\%; natomiast Rosja obejmująca 12,6\% powierzchni ziemi, na której mieszka 2,3\% ludności świata znacznie zmniejszyła swój udział w światowym potencjale gospodarczym z $2,7 \%$ do $1,1 \%$. Łącznie te trzy kraje, obejmujące $22,1 \%$ powierzchni ziemi, skupiające 39,8\% ludności, nieznacznie zwiększyły swój udział w gospodarce światowej z 5,7\% do 6,6\%. Należy wnosić, iż w najbliższych latach wobec znacznych zasobów surowcowych i tanich zasobów pracy, potencjalnie rozległych rynków, dużej atrakcyjności dla nowych lokalizacji bezpośrednich inwestycji zagranicznych oraz ogłaszanych programów rozwojowych, kraje te, przy polepszającej się sytuacji politycznej, mają szansę na znaczne przyspieszenie tempa własnego rozwoju, a także pobudzenie rozwoju pozostałych krajów.

Zarysowane dysproporcje w zakresie koncentracji potencjału gospodarczego są wynikiem bardzo zróżnicowanych warunków występujących w skali światowej. Wyrazem tego jest duża zmienność dynamiki rozwoju poszczególnych krajów, która w latach 1990-2003 wahała się od $40,6 \%$ do $357,1 \%$. Najwyższym tempem wzrostu charakteryzowała się gospodarka Chin, której wartość PKB zwiększyła się z 355 mld dol. do 1266 mld, czyli do 357,1\% oraz Irlandii (z 47 mld do 149 mld, tj. do 314,8\%). Poważną dynamiką wzrostu od 200\% do $300 \%$ charakteryzowały się gospodarki: Republiki Czeskiej (288,5\%), Słowacji (255,9\%), 
Luksemburga, Republiki Korei, Meksyku, Portugalii i Grecji. W większości są to kraje o niskim poziomie rozwoju gospodarczego, które weszły na szybką ścieżkę wzrostu gospodarczego (Chiny, Irlandia, Meksyk), kraje związane w przeszłości z centralnym systemem sterowania i wdrażające obecnie reguły gospodarki rynkowej (Republika Czeska i Słowacja) oraz kraje, które swój rozwój zawdzięczają włączenie ich do struktur UE (Portugalia, Grecja).

Znaczną dynamiką wzrostu gospodarczego (od 150\% do 200\%) odznaczało się 12 krajów, w tym kraje o najwyższym potencjale ekonomicznym Stany Zjednoczone (190,1\%), Wielka Brytania (181,4\%) oraz Norwegia (191,3\%), Nowa Zelandia, Holandia, Słowenia. W tej grupie krajów znajduje się także Polska, której wartość PKB zwiększyła się z 127 mld dol. do 210 mld dol., tj. do 164,9\%.

Słabszym tempem wzrostu (od 100\% do 150\%) cechowało się 12 krajów, a wśród nich państwa o dużym potencjale gospodarczym, przeżywające w tym czasie pewne sytuacje kryzysowe: Francja (144,5\%), Niemcy (142,3\%), Japonia (140,9\%) i Włochy (133,2\%).

Natomiast najpoważniejszym spadkiem poziomu PKB odznaczała się Rosja, której wartość PKB spadała z $579 \mathrm{mln}$ dol. do $347 \mathrm{mln}$ dol., tj. do 59,8\% oraz kraje powiązane z gospodarką rosyjską (Białoruś do 40,6\%, Ukraina do 45,5\%, Bułgaria, Węgry). W grupie tej znajdują się także wiodące kraje Ameryki Południowej (Brazylia - do 97,3\%, i Argentyna do 72,1\%) oraz Rep. Pd. Afryki (do 93,0\%), znajdujące się obecnie w kryzysowych sytuacjach politycznych i gospodarczych

Reasumując, można przyjąć, iż gospodarki poszczególnych krajów charakteryzowały się bardzo różnymi tendencjami rozwoju. W 14 krajach następował wzrost gospodarczy, na co wskazuje rosnąca systematycznie dynamika PKB. Reprezentują je kraje, które wybrały w tym czasie samodzielną ścieżkę rozwoju (Chiny, Meksyk, Norwegia, Indie, Turcja, Kanada), kraje włączone do struktur UE (Irlandia, Portugalia, Grecja), kraje o najwyższym potencjale gospodarczym (Stany Zjednoczone, Wielka Brytania) oraz kraje wdrażające reguły gospodarki rynkowej (Republika Czeska, Słowacja, Słowenia, Polska).

Systematycznym spadkiem poziomu gospodarczego charakteryzowała się Ukraina i Białoruś, które odzyskały niepodległość i poszukują własnych dróg rozwoju oraz od $1995 \mathrm{r}$. Brazylia i Rep. Pd. Afryki, które przeżywają wewnętrzne problemy polityczne, a także Japonia.

Pozostałe kraje odznaczały się zmienną dynamiką rozwoju, po pewnym spadku związanym z ogólną światową recesją gospodarczą lat 1995-2000, nastąpiło ponowne ożywienie gospodarcze. Dotyczyło to zwłaszcza większości krajów UE (Grecji, Holandii, Hiszpanii, Danii, Belgii, Francji, Niemiec, Austrii, Włoch, Szwecji, Finlandii), które w konsekwencji opracowały nowy program, mający na celu podniesienie konkurencyjności gospodarczej (tzw. Strategia Lizbońska).

$\mathrm{Na}$ zarysowane tendencje zachowań gospodarek poszczególnych krajów wpłynęła zmieniająca się sytuacja światowa, która związana była głównie z rozpadem byłej struktury krajów związanych z gospodarką centralnie sterowaną, światową recesją gospodarczą, która szczególnie zaznaczyła się wśród krajów UE oraz słabszym rozwojem gospodarki Stanów Zjednoczonych, która osłabiła swoje funkcje motoryczne w zakresie zwiększania tempa rozwoju zarówno gospodarki światowej jak i poszczególnych krajów, w tym krajów europejskich. W tej sytuacji tylko gospodarka Wielkiej Brytanii, najsilniej powiązana z gospodarką Stanów Zjednoczonych, odznaczała się ciągłym wzrostem. Należy wnosić, iż wobec dokonujących się zmian i założonych programów rozwojowych funkcje czynnika dynamizującego rozwój gospodarki światowej stopniowo przejmować będą Chiny, a w dalszych latach także Indie i Rosja.

Zróżnicowane tempo wzrostu PKB wpłynęło na zwiększenie rozpiętości potencjału gospodarczego poszczególnych krajów. Podczas gdy w 1990 r. rozpiętość ta wahała się od 7 mld dol. do 5,7 bil., czyli jak 1:821; w 1995 r. od 4 mld do 7,3 bil., czyli jak 1:1834; to w 2003 r. od 8 mld do 10,9 bil., czyli jak 1:1367. 
Postępujący w tym czasie rozwój demograficzny sprawił, iż zarysowane tempo wzrostu wartości PKB w przeliczeniu na mieszkańca, w stosunku do dynamiki ogólnej, odznaczało się niższą dynamiką (tab. 2). W latach 1990-2003 wskaźnik PKB na mieszkańca w skali światowej zwiększył się z 4,1 tys. dol. do 5,2 tys. dol., tj. do 125,6\%. Na terenie poszczególnych krajów wskaźnik ten był bardzo zróżnicowany, ale wykazywał mniejsze rozpiętości aniżeli bezwzględne wartości PKB. W 1990 r. wartość wskaźnika wahała się od 307 dol. na mieszkańca do 28,9 tys., czyli jak 1:94 a w 2003 r. od 494 dol. do 58,5 tys. dol., tj. jak 1:118.

Tab. 2. Zmiana wskaźnika wartości Produktu Krajowego Brutto na mieszkańca w latach 1990-2003.

\begin{tabular}{|c|c|c|c|c|c|}
\hline \multirow[t]{2}{*}{ Kraje } & \multicolumn{2}{|c|}{$\begin{array}{c}\text { PKB na } 1 \text { mieszkańca } \\
\text { w dol. USA }\end{array}$} & \multirow{2}{*}{$\begin{array}{c}\text { Dynamika } \\
1990-2003 \\
(1990=100) \\
2003\end{array}$} & \multicolumn{2}{|c|}{$\begin{array}{c}\text { Odchylenia } \\
\text { od średniej światowej }\end{array}$} \\
\hline & 1990 & 2003 & & 1990 & 2003 \\
\hline Świat & 4152 & 5213 & 125,6 & 100,0 & 100,0 \\
\hline Luksemburg & 28956 & 58499 & 202,0 & 697,4 & 1122,2 \\
\hline Norwegia & 27223 & 48348 & 177,6 & 655,7 & 927,5 \\
\hline Szwajcaria & 34031 & 43607 & 128,1 & 819,6 & 836,5 \\
\hline Dania & 25956 & 39335 & 151,5 & 625,1 & 754,6 \\
\hline Irlandia & 13491 & 37516 & 278,1 & 324,9 & 719,7 \\
\hline Stany Zjednoczone & 23005 & 37497 & 163,0 & 554,1 & 719,3 \\
\hline Japonia & 24705 & 33720 & 136,5 & 595,0 & 646,8 \\
\hline Szwecja & 27822 & 33668 & 121,0 & 670,1 & 645,8 \\
\hline Holandia & 19696 & 31543 & 160,1 & 474,4 & 605,1 \\
\hline Austria & 20949 & 31425 & 150,0 & 504,6 & 602,8 \\
\hline Finlandia & 27436 & 31063 & 113,2 & 660,8 & 595,9 \\
\hline W. Brytania & 17192 & 30339 & 176,5 & 414,1 & 582,0 \\
\hline Francja & 20954 & 29403 & 140,3 & 504,7 & 564,0 \\
\hline Belgia & 19931 & 29194 & 146,5 & 480,0 & 560,0 \\
\hline Niemcy & 21276 & 29092 & 136,7 & 512,4 & 558,1 \\
\hline Kanada & 20782 & 27028 & 130,1 & 500,5 & 518,5 \\
\hline Australia & 18150 & 26092 & 143,8 & 437,1 & 500,5 \\
\hline Włochy & 19437 & 25745 & 132,5 & 468,1 & 493,9 \\
\hline Nowa Zelandia & 12970 & 19745 & 152,2 & 312,4 & 378,8 \\
\hline Hiszpania & 13218 & 19685 & 148,9 & 318,4 & 377,6 \\
\hline Grecja & 8274 & 15653 & 189,2 & 199,3 & 300,3 \\
\hline Portugalia & 7219 & 14507 & 201,0 & 173,9 & 278,3 \\
\hline Rep. Korei & 5893 & 12632 & 214,4 & 141,9 & 242,3 \\
\hline Słowenia & 6343 & 11002 & 173,5 & 152,8 & 211,0 \\
\hline Rep. Czeska & 2858 & 8371 & 292,9 & 68,8 & 160,6 \\
\hline Węgry & 3261 & 8169 & 250,5 & 78,5 & 156,7 \\
\hline Meksyk & 3214 & 6219 & 193,5 & 77,4 & 119,3 \\
\hline Słowacja & 2384 & 6016 & 252,3 & 57,4 & 115,4 \\
\hline Polska & 3293 & 5486 & 166,6 & 79,3 & 105,2 \\
\hline Estonia & 4306 & 4788 & 111,2 & 103,7 & 91,8 \\
\hline Litwa & 3561 & 3977 & 111,7 & 85,8 & 76,3 \\
\hline Łotwa & 4678 & 3594 & 76,8 & 112,7 & 68,9 \\
\hline Turcja & 2681 & 3395 & 126,6 & 64,6 & 65,1 \\
\hline Argentyna & 4346 & 2689 & 61,9 & 104,7 & 51,6 \\
\hline Brazylia & 3213 & 2589 & 80,6 & 77,4 & 49,7 \\
\hline Rosja & 3915 & 2411 & 61,6 & 94,3 & 46,2 \\
\hline Rep. Pd. Afryki & 3293 & 2294 & 69,7 & 79,3 & 44,0 \\
\hline Rumunia & 1650 & 2099 & 127,2 & 39,7 & 40,3 \\
\hline Bułgaria & 2308 & 1968 & 85,3 & 55,6 & 37,8 \\
\hline Białoruś & 3431 & 1442 & 42,0 & 82,6 & 27,7 \\
\hline Chiny & 307 & 978 & 318,6 & 7,4 & 18,8 \\
\hline Ukraina & 1762 & 842 & 47,8 & 42,4 & 16,2 \\
\hline Indie & 379 & 494 & 130,3 & 9,1 & 9,5 \\
\hline
\end{tabular}

Źródło: GUS. Rocznik statystyczny, 2002, s. 734; 2004, s. 847. 
W 2003 r. najwyższymi wartościami wskaźników PKB na mieszkańca odznaczały się: Luksemburg (58,5 tys. dol.), Norwegia (48,3 tys. dol.) i Szwajcaria (43,6 tys. dol.), wysokimi wskaźnikami (od 25 tys. do 30 tys. dol.) kraje Zachodniej Europy oraz Stany Zjednoczone i Japonia. Stosunkowo niskimi wartościami wskaźników charakteryzują się nowi członkowie UE, w tym Polska (5,5 tys. dol.), natomiast najniższymi wskaźnikami Indie (456 dol.), Chiny (978 dol.) oraz kraje wdrażające reguły gospodarki rynkowej (Ukraina, Białoruś, Bułgaria, Rumunia).

Oznacza to nasilanie się procesów polaryzujących, które w zakresie poziomu rozwoju poszczególnych krajów coraz bardziej różnicują światową przestrzeń gospodarczą.

W świetle zarysowanych tendencji rozwoju należy przyjąć, iż obecnie Stany Zjednoczone i Japonia, spełniają w przestrzeni światowej funkcje dwóch wiodących biegunów wzrostu gospodarczego, które kształtują się w odmiennych uwarunkowaniach coraz silniejszej konkurencji $\mathrm{w}$ zakresie jakości oferowanych produktów, pogłębiania i rozszerzania rynków zbytu, możliwości lokalizacji oraz poszukiwania nowych miejsc dla lokowania bezpośrednich inwestycji i kapitału.

Kolejne miejsce w gospodarce światowej zajmują Niemcy, których udział w światowym PKB wynosi 7,4\%, Wielka Brytania (5,6\%), Francja (5,4\%), Włochy (4,5\%), Hiszpania $(2,6 \%)$ i Holandia $(1,6)$. Pozostałe kraje europejskie w gospodarce światowej mają znacznie mniejszą rolę, obejmując poniżej 1,0\% udziału w światowym PKB.

Kraje europejskie wobec znacznie mniejszego potencjału gospodarczego i kształtującej się w okresie powojennym nowej sytuacji światowej, miały generalnie dwa warianty rozwoju. Pierwszy wariant - samodzielnie kształtować swoją gospodarkę i wobec niewielkiego udziału potencjału funkcjonować na „,peryferiach” gospodarki Stanów Zjednoczonych i Japonii, drugi - podjąć działania na rzecz integracji własnych potencjałów gospodarczych i wspólnie tworzyć trzeci światowy biegun wzrostu. Kraje te wybrały drugi wariant i obecnie kształtują trzeci światowy biegun wzrostu gospodarczego, jakim obecnie jest Unia Europejska. Połączony potencjał gospodarczy obecnych krajów unijnych generalnie dorównuje potencjałowi gospodarczemu Stanów Zjednoczonych, co umożliwia tworzenie nowej światowej konkurencyjnej struktury gospodarczej. W latach 1990-2000 potencjał gospodarczy tych krajów w gospodarcze światowej, kształtował się odwrotnie niż gospodarki Stanów Zjednoczonych i znacznie zmniejszył się z $33,15 \%$ do $26,1 \%$, a następnie zwiększył się do $33,9 \%$ w 2003 r. Zmniejszanie się udziału krajów UE w gospodarce światowej związane jest z pojawiającym się kryzysem oraz pewnymi zaniedbaniami, np. w zakresie finansowania na rzecz wdrażania nowych technologii, trudnościami w zakresie swobodnego przepływu usług oraz hamowaniem rozwoju przedsiębiorczości. Zarysowane tendencje zmian w światowym potencjale gospodarczym są ważnym wyzwaniem dla krajów UE, które muszą zintensyfikować proces gospodarczy, aby stopniowo dorównywać potencjałowi gospodarczemu Stanów Zjednoczonych, co można osiągnąć głównie poprzez wzrost konkurencyjności gospodarek poszczególnych krajów członkowskich. Niewielkie znaczenie w strukturze UE ma ostatnio przyjęte 10 krajów Europy Środkowej, których udział w światowym potencjale gospodarczym wynosi tylko $1,4 \%$.

Obecnie te trzy wyróżnione bieguny wzrostu gospodarczego (Stany Zjednoczone, Japonia i kraje UE) w gospodarce światowej odgrywają dominującą rolę. W latach 1990-2003 ich łączny udział w światowym potencjale gospodarczym zwiększył się z 73,4\% do 81,1\%, obejmując tylko 14,1\% ludności świata i 10,0\% jego powierzchni.

Natomiast pozostałe kraje, pozostające poza wymienionymi strukturami, które obejmują 90,0\% powierzchni, zamieszkanej przez 85,9\% ludności świata, zmniejszyły swój udział w gospodarce światowej z 26,9\% w 1990 r. do 18,9\% w 2003 r.

Przedstawiona rozważania wskazują na nasilające się procesy polaryzacyjne $\mathrm{w}$ przestrzeni gospodarczej świata i należy się liczyć, iż w najbliższym czasie proces ten będzie się nieznacznie osłabiał w wyniku przyśpieszonego tempa rozwoju Chin, Indii, a także Rosji, 
których łączny udział w gospodarce światowej zwiększył się z 4,9\% w $1995 \mathrm{r}$. do 6,6\% w 2003 r., podczas gdy obejmują one 39,8\% ludności świata i 22,1\% jego obszaru.

Przedstawione rozważania wskazują na bardzo zróżnicowane i złożone otoczenie światowe i, w którym kształtuje się polska gospodarka. Wstępnym warunkiem powodzenia w zakresie jej rozwoju, jest konieczność dokonywania coraz bardziej precyzyjnych analiz, umożliwiających poznawane reguł funkcjonowania i kierunków rozwoju zarówno otoczenia światowego, jak i europejskiego, oraz zwrócenie większej uwagi na kształtowanie postaw przedsiębiorczych w polskim społeczeństwie, m.in. poprzez dobrze zorganizowany system edukacyjny. Znajomość podstaw przedsiębiorczości oraz kreowanie przedsiębiorczej jednostki, a także społeczeństwa, w warunkach nasilającej globalizacji jest niezbędne każdemu człowiekowi, który chce aktywnie włączyć się w światowe procesy rozwoju cywilizacyjnego. Poznanie tej złożonej problematyki umożliwi przedsiębiorcom umiejętne poszukiwania nisz rynkowych, podejmowanie nowych lokalizacji, zmiany istniejących profilów produkcji, przygotowywanie nowych ofert produkcyjnych czy usługowych. Ważne jest także dla władzy regionalnej czy krajowej, które winny dążyć do ponoszenia atrakcyjności swojego obszaru dla generowania własnych i przyciągania zewnętrznych kapitałów, jako nowych impulsów rozwojowych. Ważne jest także dla całego społeczeństwa, by lepiej rozumiało otaczający nas i zmieniający się świat pod względem gospodarczym, społecznym i kulturowym.

Należy bowiem przyjąć, iż tylko konkurencyjny człowiek jest w stanie wyprodukować i zaoferować konkurencyjny produkt, natomiast konkurencyjny człowiek kształtuje się w konkurencyjnym procesie edukacyjnym, w którym musi uczestniczyć konkurencyjny nauczyciel. Dopiero wówczas w pełni będzie możliwa realizacja jednego z dziesięciu priorytetów przyjętych w Narodowym Planie Rozwoju, który obejmuje - „Przedsiębiorczość rozumianą jako tworzenie nowych obszarów aktywności gospodarczej oraz zwiększenie efektywności i produktywności istniejących form gospodarowania. W tym celu niezbędne jest rozwijanie postaw przedsiębiorczych - samozaradności, innowacyjności, odpowiedzialności za los własny i wspólnoty, poprawianie otoczenia prawno-administracyjnego i prawnofinansowego przedsiębiorstw, rozwijanie rynku kapitałowego i ułatwianie przedsiębiorcom dostępu do różnych form kapitału finansowego, w tym mechanizmów mikropożyczkowych" (s. 27) ${ }^{3}$. Dlatego podjęcie szybkich działań, zmierzających do przyspieszenia wzrostu udziału polskiej gospodarki w układzie światowym i europejskim, może wpływać na stopniowe zwiększanie znaczenia naszego kraju w sterowaniu dalszymi procesami rozwoju społecznogospodarczego i kulturowego w skali europejskiej i światowej.

\footnotetext{
${ }^{3}$ Narodowy Plan Rozwoju - Wstępny Projekt 2007-2013, przyjęty przez Radę Ministrów w dniu 11 stycznia 2005 r., Ministerstwo Gospodarki i Pracy, Warszawa 2005.
} 